\title{
Evaluation of the Relationship of PD-L1 and FOXP3 Expressions With Clinicopathological Parameters in Gastric Carcinomas
}

\author{
Gastrik Karsinomlarda PD-L1 ve FOXP3 Ekspresyonlarının \\ Klinikopatolojik Parametrelerle Ilişkisinin Değerlendirilmesi
}

\section{Sevil Sayhan $\odot$, Gulden Diniz®, Duygu Ayaz®, Dudu Solakoglu Kahraman®, Pinar Ayvat $\odot$, Bulent Calik $\odot$}

Cite as: Sayhan S, Diniz G, Ayaz D, Solakoglu Kahraman D, Ayvat P, Calik B. Evaluation of the relationship of PD-L1 and FOXP3 expressions with clinicopathological parameters in gastric carcinomas. Forbes J Med. 2021;2(2):92-8.

\section{ABSTRACT}

Objective: At the time of diagnosis, gastric cancers are generally at an advanced stage and the survival rates are very low. The aim of this study is to determine the prognostic values of PD-L1 expression in gastric carcinomas and to detect the presence of FOXP3- positive Treg cells in tumor microenviroment.

Method: In this study, PD-L1 and FOXP3 expressions were evaluated in 125 patients with gastric carcinoma who had undergone gastrectomy between 2011, and 2015.

Results: The mean age of the patients was $64.18 \pm 12.3$ years and the patients were followed up for a mean period of $29.6 \pm 26.4$ months. In only $2(1.6 \%)$ cases there were weak membranous expressions of PD-L1 in tumor cells. PD-L1- positive inflammatory cells were also seen in tumors of $2(1.6 \%)$ cases. There was no significant relationship between PD-L1 expression and survival times $(p=0.690)$. In $57(45.6 \%)$ cases, FOXP3- positive lymphocytes were detected. The number of FOXP3-positive cells ranged between 1 and 55/HPF. There was no statistically significant correlation between the survival times and presence of Tregs $(p=0.793)$. Twenty-two cases $(17.6 \%)$ were evaluated as HER2-positive. There was a statistical relationship between HER2-positivity and perineural invasion $(p=0.006)$. Statistical significance between survival and some prognostic factors such as nodal metastasis $(p=0.004)$, pT stage $(p<0.01)$ and presence of perineural invasion $(p=0.010)$ was determined.

Conclusion: This study has demonstrated that the PD-L1 positivity was not effective on gastric tumorigenesis. We have found a positive correlation between the presence of Treg inflammatory cells and PD-L1 expression. But this relationship could not be proved by statistical analyses. However since PD-L1 expression was detected in only 4 cases, these findings should be confirmed in larger series.

Keywords: Gastric carcinoma, PD-L1, FOXP3, HER2, prognosis

Öz

Amaç: Mide kanserleri tanı anında genellikle ileri aşamadadır ve sağ kalım oranları çok düşüktür. $\mathrm{Bu}$ calıșmanın amacı mide karsinomlarında PD-L1 ekspresyonunun prognostik değerini belirlemek ve tümör mikro çevresindeki FOXP3 pozitif Treg hücrelerinin varlığını saptamaktır. Yöntem: Bu çalıșmada, 2011-2015 yılları arasında gastrektomi uygulanan 125 mide kanserinde PD-L1 ve FOXP3 ekspresyonları immünohistokimyasal yöntemler kullanılarak değerlendirildi. Bulgular: Hastaların ortalama yaşı $64,18 \pm 12,3$ yll olup, hastalar ortalama $29,6 \pm 26,4$ ay takip edildi. Sadece $2(\% 1,6)$ vakada tümör hücrelerinde PD-L1'in zayıf membranöz ekspresyonları vardı. PD-L1 pozitif inflamatuvar hücreler de $2(\% 1,6)$ olguda görüldü. PD-L1 ekspresyonu ile hayatta kalma süreleri arasında anlamlı bir ilişki yoktu $(p=0,690)$. Elli yedi $(\% 45,6)$ vakada FOXP3 pozitif lenfosit tespit edildi. FOXP3 pozitif hücrelerin sayısı 1 ile 55 / BBA arasında değişiyordu. Hayatta kalma süreleri ile Treg varlığı arasında istatistiksel olarak anlamlı bir iliş̧ki yoktu $(p=0,793)$. Yirmi iki olgu $(\% 17,6)$ Her2 pozitif olarak değerlendirildi. Her2 pozitifliği ile perinöral invazyon arasında istatistiksel ilişki vardı $(p=0,006)$. Sağkalım ile nodal metastaz $(p=0,004)$, $p$ T evresi $(p<0,01)$ ve perinöral invazyon varlığı $(p=0,010)$ gibi bazı prognostik faktörler arasındaki istatistiksel anlamlılık belirlendi.

Sonuç: Bu çalışma, PD-L1 pozitifliğinin mide tümörigenezi üzerine etkili olmadığını göstermiş̦tir. Treg enflamatuar hücrelerin varlığı ile PD-L1 ekspresyonu arasında pozitif bir korelasyon bulduk. Ancak bu ilişki istatistiksel analizlerle kanıtlanamadı. Ancak PD-L1 ekspresyonu sadece 4 vakada tespit edildiğinden, bu bulguların daha geniş serilerde doğrulanması gerekir.

Anahtar kelimeler: Gastrik karsinom, PDL-1, FOXP3, HER2, prognoz
Received/Geliş: 02.05.2021

Accepted/Kabul: 22.06.2021

Publication online: 13.08 .2021

Sorumlu Yazar/

Corresponding Author: Gulden Diniz

Izmir Democracy University, Pathology Department

gulden.diniz@idu.edu.tr

ORCID: 0000-0003-1512-7584

S. Sayhan 0000-0003-4783-5550

D. Ayaz 0000-0002-2202-2732

D. Solakoglu Kahraman 0000-0002-4126-5326 Izmir Tepecik Training and Research

Hospital, Pathology Laboratory

P. Ayvat 0000-0002-9941-3109 Izmir Democracy University, Anesthesiology Department

B. Calik 0000-0002-9054-1446 Izmir Bozyaka Training and Research Hospital, Surgery Clinics 


\section{INTRODUCTION}

Gastric carcinomas rank second among the most frequently seen life-threatening cancers in the world. Since at the time of diagnosis $90 \%$ of the cases are in their advanced stages, their survival rates are very low. Interactions among individual factors such as diet, Helicobacter pylori (HP) infection, environmental factors, and genetic predisposition lead to the development of gastric carcinoma. ${ }^{1-4}$ Correa's gastric carcinogenesis cascade accepted by many investigators starts with HP infection, and follows a course passing through the stages of superficial gastritis, chronic atrophic gastritis, intestinal metaplasia, dysplasia, and finally gastric carcinoma. ${ }^{5,6}$ Amplification of human epidermal growth factor receptor 2 (HER2) results in one of the intrinsic subtypes of gastric carcinomas with specific phenotypes. In gastric carcinoma, HER2 amplification is a negative prognostic factor. ${ }^{1-6}$

The balanced immune response between activator and inhibitor pathways may be disturbed in several malignancies, where the inhibition of the immune system favors tumor progression. ${ }^{7}$ Within the immune system, cytotoxic CD8 (+) and CD4 (+) Th1 T cells, along with their typically produced cytokine IFN- $\gamma$, function as the major antitumor immune effector cells, whereas other tumor- associated cells (TAC) are generally recognized as dominant tumor- promoting cells thanks to their expressions of IL-6, TNF, IL- $1 \beta$ and IL-23. ${ }^{8}$ It has been determined that in advanced stages of malignancies CD4+ helper and CD8+ cytotoxic $T$ cells increase in tumor microenvironment so as to assume an antitumoral role. $^{7}$ But not all T- lymphocytes are antitumor effector cells of the immune system. A subpopulation of CD4+ T cells expressing CD25 and Foxp3, termed as regulatory $\mathrm{T}$ cells (Tregs), play a role in promoting growth and progression of tumor cells by inhibiting the immune response against cancer. ${ }^{7}$ FOXP3 is a transcription factor and probably the best marker currently available for identifying natural Tregs in humans. ${ }^{9}$ Presence of FoxP3-positive cells within tumors has been shown to predict worse prognosis in some tumors such as cervical cancer, T-cell lymphoma, bladder cancer, lung cancer, and breast cancer.

Programmed death-ligand 1 (PD-L1) is a member of the B7 superfamily that contains the most critical costimulatory molecules that regulate $\mathrm{T}$ cell responses. ${ }^{9}$ Programmed cell death protein 1 (PD-1) is expressed on the surface of various immune cells including T-lymphocytes. PD- 1 is activated by its ligands, PD-L1 or PD-L2, and expressed by antigen-presenting cells such as macrophages and B-lymphocytes. ${ }^{10-} 12$ The interaction between PD-L1, and PD-1 attenuates lymphocyte activation, promotes development and function of Tregs, and impairs antitumor T-cell immune response. In summary, the PD-1 pathway plays a major role in the negative regulation of cell-mediated immune responses. Recently, it has been determined that PD-L1, PD-L2, and PD-1 are expressed on several tumor cells.9-12

In this study, we aimed to explore the correlation between PD-L1 and FOXP3+ Tregs in gastric adenocarcinomas and further investigate their associations with clinicopathological features.

\section{MATERIAL AND METHOD}

In this retrospective descriptive study, demographic data, and medical information related to 125 cases with gastric carcinoma treated at our institution from 2011 to 2015, including age, and gender of the patients, location, diameter and TNM stage of the tumor were retrospectively evaluated. All cases were also investigated regarding type, and grade of the tumor, lymphovascular, and perineural invasion, and lymph node involvement. This study has been conducted in accordance with the principles of the Helsinki Declaration and approved by the local Ethics Committee of the local Institutional Review Board (2019/1-9).

The paraffin block most suitable for immunohistochemical (IHC) evaluation was selected. Firstly the slide, and then the block were labeled, and cylindrical tissue samples with a diameter of $2 \mathrm{~mm}$ were harvested from donor blocks. Then microarray blocks were prepared using mapping and addressing techniques. 
IHC tests were performed using the streptavidinbiotin peroxidase method (Invitrogen, Camarillo, 85-9043, USA). Serial 5- $\mu \mathrm{m}$ sections were obtained from prepared microarray blocks and placed on slides which were baked overnight at $60^{\circ} \mathrm{C}$, dewaxed in xylene, and hydrated with distilled water through decreasing concentrations of alcohol. All slides were treated with heatinduced epitope retrieval procedure in a microwave. In this procedure slides were left for 20 minutes in $10 \mathrm{mM} / \mathrm{L}$ EDTA buffer at $\mathrm{pH} 8.0$, cooled at room temperature for 20 minutes, and then blocked to retrieve endogenous peroxidase and biotin. Purified monoclonal mouse antibodies against PD-L1 (abcam, ab-205921- pd-l1, RabMabAB, clone 28-8, 1:100 dilution) and FOXP3 (Anti-FOXP3 antibody [236A/E7] (ab20034, 1:300 dilution) were used. Two pathologists blinded to clinical characteristics of the patient performed histopathological assessments. Immune reactivity for PD-L1 was evaluated in consideration of both percentage, and intensity of complete membranous staining of tumor cells and cytoplasmic staining of inflammatory cells was also assessed (Figure 1). Immune reactivity for FOXP3 was assessed using a scoring system. FOXP3-positive lymphocytes in tumor microinviroment were counted and categorized as negative (0), weakly (+: 1 - 9 cells/ $\mathrm{HPF})$, positive $(++: 10-50$ cells/ HPF and strongly $(+++:>50$ cells/ HPF) positive (Figure 2 )

In the statistical analysis, for the comparison of the quantitative data chi-square test was used. In

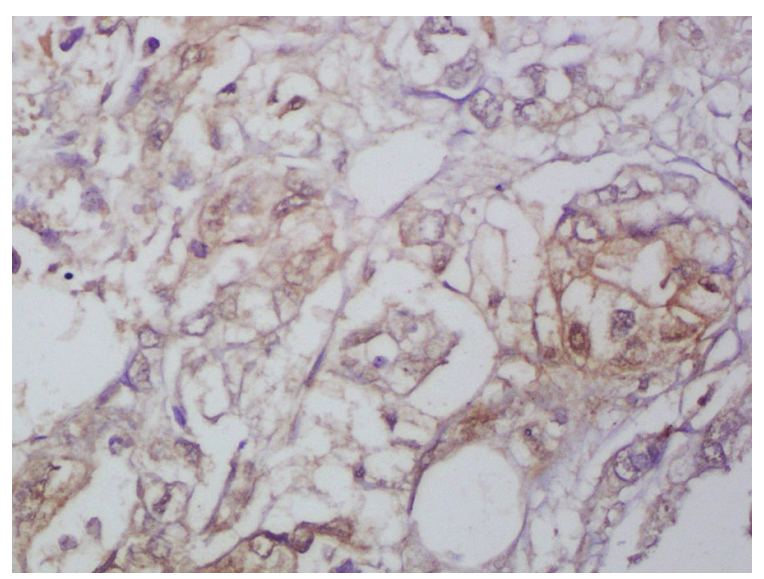

Figure 1: Weakly positive membranous PD-L1 expression in mucinous gastric carcinoma (DABx 400). the comparison of parametric data independent groups T test, and for nonparametric data MannWhitney $\mathrm{U}$ test were used. For the comparison of the measurements in more than 2 groups nonparametric Kruskal-Wallis test was utilized. P $\leq 0.05$ was accepted as the level of significance.

\section{RESULTS}

In this study 125 patients gastrectomized with the indication of gastric carcinoma were evaluated. The mean age of the patients was $64.18 \pm 12.3$ years and the patients were followed up for a mean period of $29.6 \pm 26.4$ months. Gastric carcinomas were localized on cardia in 24 (19.2 $\%)$, corpus in 58 (46.4\%), and antrum/ pylorus in $43(34.4 \%)$ cases. Mean diameter of the tumors was $6.24 \pm 3.1 \mathrm{~cm}$ (range: $1-15 \mathrm{~cm}$ ). Their histopathological subtypes consisted of poorly cohesive ( $n=42$ ), tubular ( $n=70$ ), and mixed type $(n=13)$ carcinomas. Local lymph node metastasis was detected in 99 (79.2\%) cases. Number of metastatic lymph nodes ranged between 1 , and 44 (mean: $7.4 \pm 8.5$ ) nodes. Based on TNM classification, the cases were evaluated in categories of T4 $(n=36)$, T3 $(n=75)$, T2 $(n=7)$, T1 b $(n=7), N 0(n=26), N 1 \quad(n=17), N 2(n=31), N 3 a$ $(n=29)$, and N3b $(n=22)$. Distant organ metastases were observed in $37(29.6 \%)$ cases. Metastases were localized in liver $(n=17)$, lungs $(n=11)$, peritoneum $(n=7)$, and ovaries $(n=2)$.

Using IHC and FISH methods in combination, 22 cases (17.6) were evaluated as HER2 - positive

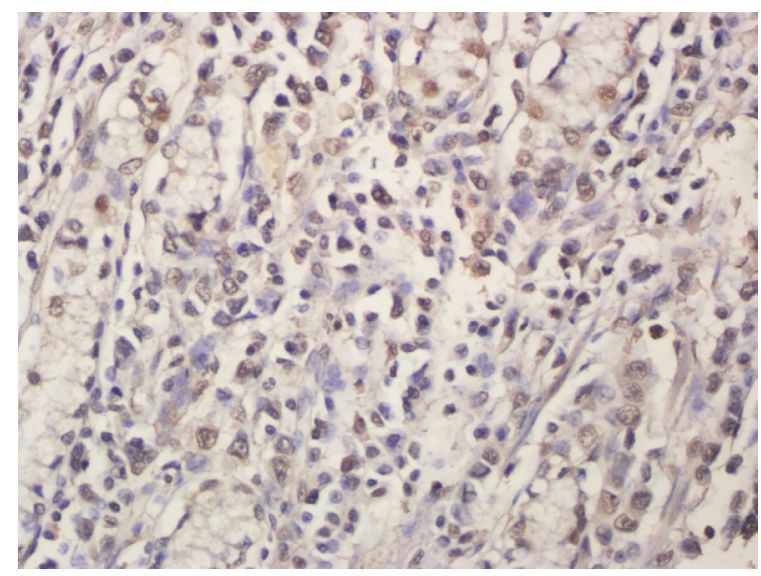

Figure 2: FOXP3- positive leucocytes interspersed among tumor cells in poorly cohesive gastric carcinoma (DAB x 200). 
and all of them had received targeted therapy. HER2- positive tumors were localized in gastric cardia $(n=3)$, corpus $(n=16)$ or pylorus $(n=3)$. There was no statistically significant relationship between HER2 status and tumor localization ( $p$ : 0.346). The percentage of metastatic cases in HER2- positive group (45.5\%) was higher than HER2- negative group (26.2\%). Similarly, the mortality rate in the HER2 positive group (77.3\%) was slightly higher than the negative group (68\%). However, there was no statistically significant difference between HER2 positivity , metastasis $(p=0.073)$ and survival $(p=0.389)$.

The average ages of the patients with HER2 positive, and negative tumors were 61.4 , and 64.7 years, respectively. The average tumor diameters of HER2 positive and negative tumors were $6.5 \mathrm{~cm}$, and $6.1 \mathrm{~cm}$, respectively. Poorly cohesive carcinomas accounted for 36 (35\%) of HER2 negative, and 6 (27.3\%) of HER2 positive cases. While lymph node metastases were seen in $72.7 \%$ of HER2 positive, and $80.6 \%$ of HER2 negative tumors. When we compared the T stage according to HER2 status, $77.3 \%$ of the HER2positive tumors, whereas almost all of the HER2negative tumors (91.3\%) were advanced-stage tumors such as PT3 and T4. However, there was no statistically significant relationship between Her2 status and age (p: 0.289), tumor size ( $p$ : 0.682), histologic tumor type (p: 0.346), lymph node metastasis ( $p: 0.410)$, and tumor stage ( $p$ : 0.059 ). Perineural invasion (PNI) was detected in $65 \%$ of HER2- negative, and $31.8 \%$. of HER2positive patients. A statistically significant relationship was found between perineural invasion and HER2 status (p: 0.006).

In only 2 cases (1.6\%), there were weak membranous expressions of PD-L1 in tumor cells (Figure 1). PD-L1 - positive inflammatory cells were also seen in 2 tumors (1.6\%). There was no significant relationship between PD-L1 expression and survival rates $(p=0,690)$. In $57(45.6 \%)$ cases, there were FOXP3- positive lymphocytes (Figure 2). Number of FOXP3- positive cells ranged between 1 and 55/ HPF. There was no statistically significant correlation between the survival times and the presence of Tregs $(p=0.793)$. However statistically significant correlations were determined between survival times, presence of nodal metastases $(p=0.004)$, pT stage $(p<0.01)$ and perineural invasion $(p=0,010)$.

\section{DISCUSSION}

PD-1 - PD-L1 pathway and Treg cells are important in maintaining peripheral tolerance in gastric cancers as in other tumors. ${ }^{13-16}$ PD-1 and PD-L1 play leading roles in the escape of tumor cells from the host immune system. ${ }^{17-19}$ PD-L1 is effective in the formation, proliferation and maintenance of FOXP3 expression in Treg cells. Treg cells act as mediators by suppressing effector T cells and inhibiting immune-mediated damage. ${ }^{7}$, 20- 23 Some researchers have suggested that FOXP3-positive $\mathrm{T}$ cells in humans have heterogeneous function, and contain suppressor Treg cells and nonsuppressor simple T cells. Nonsuppressor simple T cells are natural CD $4+\mathrm{T}$ cells that show transient FOXP3 expression by stimulation of $\mathrm{T}$ cell receptors (TCRs). ${ }^{24-26}$

Ying et al. ${ }^{1}$ revealed that PD-L1 expression in gastric cancer tissue and Treg cells infiltrating the tumor increased and CD 8 cells decreased compared to neighboring normal tissue. However, they suggested that demonstration of these immune markers individually in gastric cancer patients was not associated with prognosis. In contrast, they showed that combinations of CD8/ FOXP3 and CD8/ PD-L1 ratios determine subgroups of patients with different survival times. ${ }^{1}$ Similar findings have been suggested in previous publications. ${ }^{3,5,27}$

Wang et al. ${ }^{28}$ also showed that high PD-L1 expression positively correlated with CD8 + T cells in the tumors of patients with advanced gastric cancer. They demonstrated that PD-L1 expression and high density $\mathrm{CD} 8+\mathrm{T}$ cells were associated with good prognosis and PD-L1 expression and high density of FOXP3 + Treg cells with poor prognosis.. ${ }^{28}$ According to these researchers, multivariate Cox regression analysis revealed that CD8 + T cell density acts as the only independent predictor of overall survival times. However, Thompson et al. ${ }^{11}$ demonstrated increases in 
PD-L1 expression and intratumoral / stromal CD8 $+\mathrm{T}$ cell density had been associated with poor prognosis in both tumor cells and immune cells surrounding the tumor. This may be explained by the adaptive immune resistance mechanism. ${ }^{11}$ Only $2(1.6 \%)$ of our cases had PD-L1 (+) tumor cells, and 57 had FOXP3 + Treg cells in infiltrating cells. Any correlation between survival times and FOXP3 + Treg cells was not detected.

In our series, HER2-positive tumors were not PD-L1-expressing tumors. On the other hand, 10 HER2-positive tumors had FOXP3-positive lymphocytes, whereas 47 HER2-negative tumors contained lymphocytes expressing FOXP3. There was no statistically significant relationship between HER2 -negative and positive groups as for FOXP3 expressions. In our study, no statistically significant relationship was found between PD-L1 expression and the survival times of the patients with gastric cancer. When histological types of tumors were examined according to PD-L1 positivity, any difference in histological types of tumors was not detected in PD-L1- positive and negative groups. When tumor location and PD-L1 positivity were compared, two PD-L1 positive tumors were located in the corpus and two in the pylori. Interestingly, none of $\mathrm{PD}-\mathrm{L} 1$ positive tumors were located in cardia. However, chi-square test could not be performed because of the small number of PD-L1 positive tumors in one group, and lack of any PD-L1 -positive tumors in the other group.

Any statistically significant correlation was not found between PD-L1 expression, and other relevant parameters as tumor size, pathological tumor stage ( $\mathrm{pT})$, lymphovascular and perineural invasion, lymph node metastasis. Survival analysis of patients performed based on PD-L1 expression rates and in consideration of mortality rates, and survival times did not reveal a statistically significant relationship between PD-L1 expression and survival times. These results are partially consistent with the study results of Zhang et al. ${ }^{14}$ However, we did not find a positive correlation between PD-L1 expression and shorter overall survival times.

Interestingly, survival analysis of the patients revealed longer overall follow-up and survival times in PD-L1 negative group. However, this difference was not found to be statistically significant in Kaplan- Meier survival analysis. Response to anti-PD-L1 immunotherapy correlates with intense staining of tumor cells with CD8 and PD-L1 immune markers in renal cell carcinoma, malignant melanoma, and non-small cell lung carcinoma. ${ }^{29-33}$ Therefore, FDA has approved the treatment of similar tumors with immune checkpoint inhibitors. ${ }^{34}$ However, FDA has not approved this treatment for stomach cancers. In addition, some patients are resistant to this treatment. There are different opinions related to the mechanism of this resistance. ${ }^{35}$ Proliferation of CD8 + T cells infiltrating the tumor has been suggested to have an impact on the treatment. ${ }^{8,36,37}$ Large series of studies should be performed on immune blockade therapies targeting PD-1 and PD-L1 in gastric carcinomas. ${ }^{14,38}$ In various studies, pembrolizumab and nivolumab treatment has been reported to be effective in PD-L1 positive cases with relapsing or metastatic gastric carcinoma. ${ }^{39,40}$

In conclusion, we did not find a statistically significant relationship between PD-L1 expression and patient survival and other pathological and molecular features of tumors in tumor cells and the surrounding immune cells in 125 cases with gastric carcinoma. The same was true for FOXP3positive Treg cells in the tumor microenvironment. Indeed, a statistically significant correlation was not found between these cells, survival times, and other characteristic features of the tumors. Gastric cancer is one of the most important malignancies with high mortality and morbidity rates. Tumor size, lymph node involvement, presence of distant metastasis, and histological grade of the tumor are not sufficient to determine the prognosis of gastric cancer patients. ${ }^{1}$ Molecular innovations have not contributed much in this regard. ${ }^{2}$ Recent studies demonstrating that the microenvironment characteristics of the tumor may have an impact on the prognosis of patients have yielded promising clues. ${ }^{3,7}$ FOXP3 and PD-L1 expressions have been widely studied so as to predict clinical response in several cancers. ${ }^{13-18}$ However, their expressions and impacts on the prognosis of patients with gastric carcinoma have not been well studied and 
remained as controversial issues. In this study, we aimed to explore the correlation between PD-L1 and FOXP3 + Tregs in gastric cancers and couldn't find any association between them. But further researches should be conducted to reveal their associations with clinicopathological features.

Ethics Committee Approval: The study protocol was approved by the Local Ethics Committee of Tepecik Education and Research Hospital (2019/1-9).

Conflict of Interest: No conflict of interest has been declared by the authors.

Funding: The authors of this research did not receive any specific grant from any funding agency in the public, commercial, or not-for-profit sectors.

Informed Consent: As the study was retrospective, consent was not obtained from the patients.

\section{REFERENCES}

1. Ying L, Yan F, Meng Q, Yu L, Yuan X, Gantier MP, et al. PD-L1 expression is a prognostic factor in subgroups of gastric cancer patients stratified according to their levels of CD8 and FOXP3 immune markers. Oncolmmunology 2018; 7, 6, e1433520. https://doi.org/10.1080/2162402X.2018.1433520

2. Ajani JA, Lee J, Sano T, Janjigian YY, Fan D, Song S. Gastric adenocarcinoma. Nat Rev Dis Primers 2017; 3:17036.10.1038/ nrdp.2017.36. PMID:28569272 https://doi.org/10.1038/nrdp.2017.36

3. Hou J, Yu Z, Xiang R, Li C, Wang L, Chen S, et al. Correlation between infiltration of FOXP3+ regulatory $\mathrm{T}$ cells and expression of $\mathrm{B} 7-\mathrm{H} 1$ in the tumor tissues of gastric cancer. Experimental and molecular pathology 2014; 96: 284-91. https://doi.org/10.1016/j.yexmp.2014.03.005

4. Quail DF, Joyce JA. Microenvironmental regulation of tumor progression and metastasis. Nat Med 2013; 19: 1423-37. https://doi.org/10.1038/nm.3394

5. Wen T, Wang Z, Li Y, Li Z, Che X, Fan Y, et al. A four- factor immunoscore system that predicts clinical out-come for stage II/ III gastric cancer. Cancer Immunol Res 2017;5:524-34. https://doi.org/10.1158/2326-6066.CIR-16-0381

6. Kim JW, Nam KH, Ahn SH, Park DJ, Kim HH, Kim $\mathrm{SH}$, et al. Prognostic implications of immunosuppressive protein expression in tumors as well as immune cell infitration within the tumor microenvironment in gastric cancer. Gastric Cancer 2016; 19(1): 42-52. https://doi.org/10.1007/s10120-014-0440-5

7. Li Z, Dong P, Ren M, Song Y, Qian X, Yang Y, et al. PD-L1 Expression is associated with tumor FOXP3+ regulatory T-cell infiltration of breast cancer and poor prognosis of patient. Journal of cancer 2016;7:784-93.

https://doi.org/10.7150/jca.14549

8. Tumeh PC, Harview CL, Yearley JH, Shintaku IP, Taylor EJ, Robert L, et al. PD-1 blockade induces responses by inhibiting adaptive immune resistance. Nature 2014;515:568-71. https://doi.org/10.1038/nature13954

9. Shen LS, Wang J, Shen DF, Yuan XL, Dong P, Li MX, et al. CD4(+) CD25(+) CD127 (low/-) regulatory T cells Express Foxp3 and supress effector $\mathrm{T}$ cell proliferation and contribute to gastric cancers progression. Clin Immunol 2009;131:109-18. PMID: 19153062. https://doi.org/10.1016/j.clim.2008.11.010

10. Kahraman DS, Diniz G, Sayhan S, Sayar C, Ayaz D, Gokcu M, Karadeniz T. The prognostic significance of PD-L1 and foxp3 expressions in tumor cells and the tumor microenvironment of ovarian epithelial tumors. Int J Clin Exp Pathol 2018;11(8):3884-90.

11. Thompson ED, Zahurak M, Murphy A, Cornish T, Cuka N, Abdelfatah E, et al. Patterns of PD-L! Expression and CD8 $\mathrm{T}$ cell infiltration in gastric adenocarcinomas and associated immune stroma. Gut 2017; 66: 794-801. https://doi.org/10.1136/gutjnl-2015-310839

12. Chinai JM, Janakiram $M$, Chen F, Chen W, Kaplan $M$, Zang $X$. New immunotherapies targeting the PD-1 pathway. Trends Pharmacol Sci 2015; 36: 587-95. PMID:26162965. https://doi.org/10.1016/j.tips.2015.06.005

13. Jin HT, Ahmed R, Okazaki T. Role PD-1 in regulating t-cell immunity. Current topics in microbiology and immunology 2011; 350:17-37. https://doi.org/10.1007/82_2010_116

14. Zhang M, Dong Y, Liu H, Wang Y, Zhao S, Xuan Q, et al. The clinicopathological and prognostic significance of PD-L1 expression in gastric cancer: a meta-analysis of 10 studies with 1901 patients. Scientific Reports 2016; 6:37933.10.1038/ srep37933. PMID:27892511. https://doi.org/10.1038/srep37933

15. Qing Y, Li Q, Ren T, Xia W, Peng Y, Liu GL, et al. Upregulation of PD-L1 and APE 1 is associated with tumorigenesis and poor prognosis of gastric cancer. Drug Design Dev Therapy 2015; 9: 901-9. PMID:25733810. 1. https://doi.org/10.2147/DDDT.S75152

16. Saito H, Kono Y, Murakami Y, Shishido Y, Kuroda $\mathrm{H}$, Matsunaga T, Fukumoto $\mathrm{Y}$, et al. Highly Activated PD-1/PD-L1 Pathway in Gastric Cancer with PD-L1 Expression. Anticancer Res 2018; 38(1):107-112. PMID:29277762. https://doi.org/10.21873/anticanres.12197

17. Brahmer JR, Tykodi SS, Chow LQ, Hwu WJ, Topalian SL. Safety and activity of anti-PD-L1 antibody in patients with advanced cancer. The New England journal of medicine 2012; 366: 2455-65. https://doi.org/10.1056/NEJMoa1200694

18. Droeser RA, Hirt C, Viehl CT, Frey DM, Nebiker C, 
Huber X, et al. Clinical impact of programmed cell death ligand 1 expression in colorectal cancer. European journal of cancer 2013; 49:2233-42. https://doi.org/10.1016/j.ejca.2013.02.015

19. Saito H, Kuroda H, Matsunaga T, Osaki T, Ikeguchi $M$. Increased PD-1 expression on CD4+ and CD8+ $T$ cells is involved in immune evasion in gastric cancer. J Surg Oncol 2013; 107: 517-22. PMID23129549. https://doi.org/10.1002/jso.23281

20. Francisco LM, Salinas VH, Brown KH, Vanguri VK, Freeman GJ; Kuchroo VK, et al.PD-L1 regulates the development,maintenance,and function of induced regulatory T cells. J Exp Med 2009; 206:3015-29. https://doi.org/10.1084/jem.20090847

21. Yagi H, Nomura T, Nakamura K, Yamazaki $S$, Kitawaki T, Hori S, et al. Crucial role of FOXP3 in the development and function of human CD25+CD4+ regulatory $\mathrm{T}$ cells. International immunology 2004; 16: 1643-56.

https://doi.org/10.1093/intimm/dxh165

22. De Reuver PR, Mehta S, Gill P, Andrici J, D'Urso L, Clarkson A, Mittal A, et al. Immunoregulatory Forkhead box protein p3-positive lymphosytes are associated with overall survival in patients with pancreatic neuroendocrine tumors," Journal of the American College of Surgeons 2016; 222(3): 281-7. https://doi.org/10.1016/j.jamcollsurg.2015.12.008

23. Que Y, Xiao W, Guan YX, Liang Y, Yan SM, Chen HY, et al. PD-L1 expression is associated with FOXP3+ regulatory T-Cell infiltration of soft tissue sarcoma and poor patient prognosis. J Cancer 2017; 8:2018-25. https://doi.org/10.7150/jca.18683

24. Kamada T, Togashi Y, Tay C, Ha T, Sasaki i, et al. PD-1 + regulatory T cells amplified by PD-1 blockade promote hyperprogression of cancer. Proc Ntl Acad Sci 2019; $116(20):$ 9999-10008. https://doi.org/10.1073/pnas.1822001116

25. Wing JB, Tanaka A, Sakaguchi S. Human FOXP3+ regulatory $\mathrm{T}$ cell heterogeneity and function in autoimmunity and cancer. Immunity 2019; 50: 302-16. https://doi.org/10.1016/j.immuni.2019.01.020

26. Campbell DJ, Ziegler SF. FOXP3 modifies the phenotypic and functional properties of regulatory T cells. Nat Rev Immunol 2007; 7: 305-10. https://doi.org/10.1038/nri2061

27. Geng Y, Wang H, Lu C, Li Q, Xu B, Jiang J, et al. Expression of costimulatory molecules B7-H1, B7-H4 and Foxp3(+) Tregs in gastric cancer and its clinical significance. International journal of clinical oncology 2015; 20: 273- 81 . https://doi.org/10.1007/s10147-014-0701-7

28. Wang Y, Zhu C, Song W, Li J, Zhao G, Cao H. PD-L1 Expression and CD8+ $\mathrm{T}$ cell infiltration predict a favorable prognosis in advanced gastric cancer. Journal of Immunology Research 2018; ID4180517, 10 pages. https://doi.org/10.1155/2018/4180517

29. Hino R, Kabashima K, Kato Y, Yagi H, Nakamura M, Honjo T, et al. Tumor cell expression of programmed cell death-1 ligand 1 is a prognostic factor for malignant melanoma. Cancer 2010;116:1757-66. https://doi.org/10.1002/cncr.24899

30. Taube JM, Klein A, Brahmer JR, Xu H, Pan X, Kim JH, et al. Association of PD-1, PD-1 ligands, and other features of the tumor immune microenvironment with response to anti-PD-1 therapy. Clin Cancer Res 2014; 20(19):5064-74.

https://doi.org/10.1158/1078-0432.CCR-13-3271

31. Libson EJ, Sharfman WH, Drake CG, Wolner I, Taube $J M$, Anders RA, et al. Durable cancer regression offtreatment and effective reinduction therapy with an anti-PD-1 antibody. Clin Cancer Res2013;19(2):462-8. https://doi.org/10.1158/1078-0432.CCR-12-2625

32. Schmidt LH, Kummel A, Gorlich D, Mohr M, Brockling S, Mikesch JH, et al. PD-1 and PD-L1 Expression in NSCLC Indicate a Favorable Prognosis in Defined Subgroups. PLoSOne 2015;10(8):e0136023.

https://doi.org/10.1371/journal.pone.0136023

33. Leite KR, Reis ST, Junior JP, Zerati M, Gomes DdeO, Camara-Lopes LH, et al. PD-L1 expression in renal cell carcinoma clear cell type is related to unfavorable prognosis. Diagn Pathol 2015;10:189. https://doi.org/10.1186/s13000-015-0414-x

34. Pardoll DM. The blockade of immune checkpoints in cancer immunotherapy. Nature Reviews Cancer 2012; 12(4): 252-64. https://doi.org/10.1038/nrc3239

35. Colwell J. Is PD-L1 expression a biomarker of response? Cancer Discovery 2015;5:1232.10.1158/2159-8290. CD-ND2015004. PMID:26516064.

https://doi.org/10.1158/2159-8290.CD-ND2015-004

36. Turcotte S, Gros A, Tran E, Lee CC, Wunderlich JR, Robbins PF, et al. Tumor-reactive CD8+ T cells in metastatic gastrointestinal cancer refractory to chemotherapy. Clin Cancer Res 2014; 20:331-43. CCR-13-1736: PMID:24218514. https://doi.org/10.1158/1078-0432.CCR-13-1736

37. Lee HE, Chae SW, Lee YJ, et al. Prognostic implications of type and density of tumourinfiltrating lymphocytes in gastric cancer. British Journal of Cancer 2008; 99(10):1704-11. https://doi.org/10.1038/sj.bjc.6604738

38. Topalian SL, Drake CG, Pardoll DM. Immune checkpoint blockade: a common denominator approach to cancer therapy. Cancer Cell 2015;27(4): 450-61. https://doi.org/10.1016/j.ccell.2015.03.001

39. Muro K, Chung HC, Shankaran V, Geva R, Catenacci D, Gupta S, et al. Pembrolizumab for patients with PD-L1-positive advanced gastric cancer (KEYNOTE-012): a multicentre, open-label, phase 1b trial. Lancet Oncol 2016; 17(6):717-726. https://doi.org/10.1016/S1470-2045(16)00175-3

40. Mishima S, Kawazoe A, Nakamura Y, Sasaki A, Kotani D, Kuboki Y, et al. Clinicopathological and molecular features of responders to nivolumab for patients with advanced gastric cancer. J Immunother Cancer 2019; 7(1): 24. https://doi.org/10.1186/s40425-019-0514-3 